\title{
SPACE SYNTAX TO RESEARCH THE TRAFFIC IMPACT AREA OF URBAN RETAIL STORES ON SPATIAL PATTERNS OF ROAD NETWORK
}

\section{A.L.A.C. PATHIRAJA, P.C.P. DE SILVA\&AMILA B. JAYASINGHE}

Department of Town \& Country Planning, University of Moratuwa, Moratuwa, Sri Lanka

\begin{abstract}
Retail stores along the road network generate additional traffic and it changes the spatial travel pattern of the street network. Therefore, it is better to understand the spatial configurations and classify the retail spatial pattern of the retail stores at the early stage of retail development. Therefore, this article objects to delineate the traffic impact area based on spatial patterns of the street network at retail stores in Colombo, Sri Lanka using the space syntax analysis from depth map software with GIS technique. Thus, this paper tends to derive the possible traffic impact area on the spatial configuration of the road network at supermarkets by calculating the level of integration, choice, connectivity, angular connectivity and normalized choice of the street network by the way of space syntax technique. Further, this paper categorizes the traffic impact areas of retail activity through the GIS overlay tool. The finding of this paper support to get a better understanding of the spatial patterns at the urban retail stores in Colombo area. This paper tends to make efficient locational based decision-makings for urban planning interventions based on the spatial configuration in Colombo city.
\end{abstract}

KEYWORDS: GIS, Traffic Impact Area, Space Syntax, Spatial Patterns\& Urban Retail Stores

Received: Jun 08, 2020; Accepted: Jun 28, 2020; Published: Sep 14, 2020; Paper Id.: IJMPERDJUN20201220

\section{INTRODUCTION}

Location is the primary consideration for retail business at the early stage of retail development[1]. A better location is the success of the business and as similarly poor location affects it negatively[2]. Therefore, an optimum location for retail development should be selected for a better business plan. The majority of urban retail stores are distributed along with the street network in a city[3]. People have more attention to the pass functions of their journey from origin to destination[4]due to the additional transport access costs [5]. Therefore, economic activities are habitually originated along with the road network. Therefore, the transport system should be optimized to maximize the economic benefit of a city. In the other hand, traffic congestion will be produced along with the road network. Many cities suffer from road traffic congestion. Travel behaviors for destinations and connectivity of the road network are the main reason for that. Therefore, new retail developments can be largely affected by the spatial pattern of the road network [6]. Hence, this paper objects to delineate the traffic impact area based on spatial patterns of the street network at retail stores in Colombo, Sri Lanka using the space syntax analysis with GIS platform.Further, the finding of this research illustrates that the supermarkets are located at the very highly connected and very highly integrated locations. A proper understanding of the spatial patterns of retail activities in the urban context is beneficial for the real-world phenomena of urban planning in a city [2]. Moreover, this paper supports to develop market strategies and to identify the potential patronage areas for the businesses, and the planning and economic analysis. 


\section{LITERATURE REVIEW}

Space syntax is mostly applied for urban and transport planning phenomena [7]. Space syntax technique demonstrates the relationship between society and space [8]. This technique illustrates how spaces are used concerning other factors [9]. This is based on the configurational axial map of the space [10]. Traditionally, space syntax applies to analyze the effects of space configuration [7].Integration values indicate the attractiveness of the space and it can use to identify the potential routes to travel for the destinations[8]. The space syntax methodology is potential to apply for urban transport phenomena to analyze the effects of urban configuration [7]. Therefore, most past studies seek to apply space syntax approach to address the issue of urban agglomerations effects and other space-based urban and transport planning issues.The aggregated traffic flow of the road network in the urban areas of Cardiff, United Kingdom was modelled by using the space syntax technique successfully in 2016 [11]. This study was more useful in the early stages to measure the traffic flow changes to make city planning strategies.

Interaction between the spatial pattern of the retail activity and road network in Israeli cities was measured through the space syntax analysis [3]. The finding of this paper shows that a weak relationship is having between retail activity pattern and the road network in Israeli cities. This paper detailed that the retail pattern of a city differsin its characteristics. Therefore, they explained that the spatial pattern of retail activities in new citiesand old cities are significantly different. The retail pattern of old cities is integrated along the major roads. Besides, the new cities tend to disperse the retail activities within the city equally in Israelias the neighbourhood concept [3]. Accordingly, this technique is extremely useful for planning interventions. The space syntax is applied by [12] to detect the spatial shopper behaviour of a supermarket. This was successfully applied to find the relationships between shopper movement flows and spatial accessibility to identify the spatial configuration of the store. Accordingly, space syntax analysis with Geographical Information System (GIS) software is usually applied for most spatial analysis in an urban context by most scholars.

\section{METHOD OF STUDY}

This analytical method uses space syntax approach from Depth Map Software to detect the traffic impact areas based on the spatial patterns of the road network at urban retail activities through the connectivity, angular connectivity, integration, choice, and normalized choice analysis. Further, the GIS overlay technique is used to identify the overall traffic impact areas of urban retail activities by applying integration, connectivity and choice factors. Therefore, below 11 urban retail locations in Colombo area are randomlyselected forresearch development.

Table 1: Supermarket Locations

\begin{tabular}{|c|l|l|}
\hline Location No. & \multicolumn{1}{|c|}{ GPS Location } & \multicolumn{1}{c|}{ Address } \\
\hline 1 & $6^{\circ} 55^{\prime} 04.2^{\prime \prime} \mathrm{N} 79^{\circ} 51^{\prime} 40.6^{\prime \prime} \mathrm{E}$ & No: 69, Hyde Park Corner, Colombo 2 \\
\hline 2 & $6^{\circ} 53^{\prime} 46.1^{\prime \prime} \mathrm{N} 79^{\circ} 52^{\prime} 22.6^{\prime \prime} \mathrm{E}$ & No: 407, Thimbirigasyaya Road, Colombo 05 \\
\hline 3 & $6^{\circ} 58^{\prime} 09.3^{\prime \prime} \mathrm{N} 79^{\circ} 52^{\prime} 25.1^{\prime \prime} \mathrm{E}$ & No: 854, Aluthmawatha Road, Mattakkuliya \\
\hline 4 & $6^{\circ} 55^{\prime} 15.1^{\prime \prime} \mathrm{N} 79^{\circ} 51^{\prime} 42.4^{\prime \prime} \mathrm{E}$ & No: 460, T.B. Jaya Mawatha, Colombo 10 \\
\hline 5 & $6^{\circ} 55^{\prime} 18.1^{\prime \prime} \mathrm{N} 79^{\circ} 51^{\prime} 22.0^{\prime \prime} \mathrm{E}$ & No: 199, Union Place, Colombo 2 \\
\hline 6 & $6^{\circ} 56^{\prime} 54.3^{\prime \prime} \mathrm{N} 79^{\circ} 51^{\prime} 39.5^{\prime \prime} \mathrm{E}$ & No: 01, Bonjeang Road, Colombo 13 \\
\hline 7 & $6^{\circ} 53^{\prime} 13.0^{\prime \prime} \mathrm{N} 79^{\circ} 51^{\prime} 51.4^{\prime \prime} \mathrm{E}$ & No: 228, Havelock Road, Colombo 05 \\
\hline 8 & $6^{\circ} 54^{\prime} 50.4^{\prime \prime} \mathrm{N} 79^{\circ} 52^{\prime} 51.9^{\prime \prime} \mathrm{E}$ & No: 85, Cotta Road, Borella \\
\hline 9 & $6^{\circ} 51^{\prime} 48.0^{\prime \prime} \mathrm{N} 79^{\circ} 52^{\prime} 00.2^{\prime \prime} \mathrm{E}$ & No: 53, Hospital Road, Kalubowila, Dehiwala \\
\hline 10 & $6^{\circ} 52^{\prime} 11.4^{\prime \prime} \mathrm{N} 79^{\circ} 52^{\prime} 50.7^{\prime \prime} \mathrm{E}$ & No: 135, DutugemunuMawatha, Kohuwala \\
\hline 11 & $6^{\circ} 52^{\prime} 46.4^{\prime \prime} \mathrm{N} 79^{\circ} 52^{\prime} 33.4^{\prime \prime} \mathrm{E}$ & No: 25, Edmonton Road, Colombo 05 \\
\hline
\end{tabular}


This analytical method derives to demarcate the traffic impact areas according to thetravel patterns of the road network and categorizes spatial patterns at retail stores in Colombo, Sri Lanka. The finding of this method support to get a better understanding of the travel behaviours at the urban retail stores in Colombo area.

\section{ANALYSIS AND RESULTS}

Transportation is strongly influenced bythe spatial patterns of the city [13]. Depth Map software was used to calculate the axial integration of roads, connectivity, choice, normalized choice and angular connectivity. They were classified into five classes based on the Natural Breaks (Jenks) classification by using Arc GIS. Accordingly, all layers are classified in to as below.

Table 2: Layer Classifications

\begin{tabular}{|c|c|c|c|c|c|c|}
\hline $\begin{array}{c}\text { Class } \\
\text { Description }\end{array}$ & $\begin{array}{l}\text { Colour } \\
\text { Code }\end{array}$ & Integration & Connectivity & Choice & $\begin{array}{c}\text { Normalized } \\
\text { Choice }\end{array}$ & $\begin{array}{c}\text { Angular } \\
\text { Connectivity }\end{array}$ \\
\hline Very Low & $\longrightarrow$ & $\begin{array}{l}-1.000000 \\
768.000000\end{array}$ & $0-1$ & 0 - 11973319 & $\begin{array}{ll}0.000000 & - \\
0.436893 & -\end{array}$ & $\begin{array}{l}0.000007 \\
0.138681\end{array}$ \\
\hline Low & $\square$ & $\begin{array}{l}768.000001 \\
2235.554400\end{array}$ & $1-2$ & $\begin{array}{l}11973319 \\
36482184\end{array}$ & $\begin{array}{l}0.436894 \\
0.987542\end{array}$ & $\begin{array}{l}0.138682 \\
0.367101\end{array}$ \\
\hline Moderate & & $\begin{array}{l}2235.554401 \\
2728.795400\end{array}$ & $2-3$ & $\begin{array}{l}36482184 \\
69957248\end{array}$ & $\begin{array}{l}0.987543 \\
1.197596\end{array}$ & $\begin{array}{l}0.367102 \\
0.806916\end{array}$ \\
\hline High & $\longrightarrow$ & $\begin{array}{l}2728.795401 \\
3240.607400\end{array}$ & $3-4$ & $\begin{array}{l}69957248 \\
172046980 \\
\end{array}$ & $\begin{array}{l}1.197597 \\
1.655912 \\
\end{array}$ & $\begin{array}{l}0.806917 \\
1.578353 \\
\end{array}$ \\
\hline Very High & & $\begin{array}{l}3240.607401 \\
4783.665500\end{array}$ & $4-6$ & $\begin{array}{l}172046980 \\
296088000\end{array}$ & $\begin{array}{l}1.655913 \\
3.266712\end{array}$ & $\begin{array}{l}1.578354 \\
4.248782\end{array}$ \\
\hline
\end{tabular}

The integration analysis measure how roads are integrated or central to the road network. According to the integration analysis from Depth Map Software, supermarket No: 03 is located at a moderately integrated location and No: 06 and 10 are located at a highly integrated urban space. All other supermarkets are intended along with the very highly integrated road network. Figure 1 shows that there is an averagely very high integration near the supermarkets in Colombo area. The connectivity analysis measures the connectivity or linkages of the street in each other. It clearly shows how many streets are connected. According to the connectivity analysis from Depth Map Software, supermarket No: 02, 04, 09 and 10 are placed at a location with moderate connectivity. All other supermarkets are intended along with the highly connected road network. It may convenient to easy access for suppliers and customers also. Figure 2 shows that there is averagely high connectivity near the supermarkets in Colombo area.

According to the angular connectivity analysis from Depth Map Software, All the supermarkets are intended along with the very highly connected road network. It is very easy to make high attraction for the customers. Below map shows it clearly. Together, there is an averagely very high angular connectivity near the supermarkets in Colombo area (Figure 3). The choice measures how roads are important to link to the network as a through-road. It identifies the importance of the road to the function of the transport network. According to the Angular Segment Analysis from Depth Map Software, supermarket No: 06 and 10 have very low importance, supermarket No: 01, 02, 04, and 05 have low importance, 03, 07 and 08 have moderate importance, and 09 and 11 have high importance value to connect to the road network. Together, averagely, there is moderate importance to link to the road network for supermarket locations in Colombo area (Figure 4). According to the normalized choice analysis from Depth Map Software, the only supermarket No: 06 and 10 have moderate importance and all other supermarkets have high importance to connect to the road network 
easily. Further, there is an average high importance to link to the road network for supermarket locations in Colombo area (Figure 5).

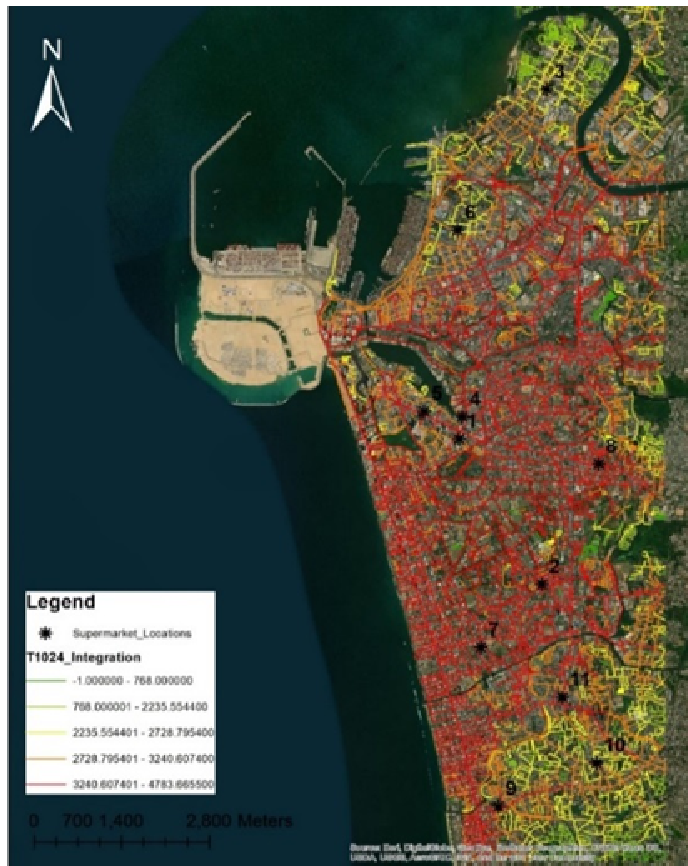

Figure 1: Integration

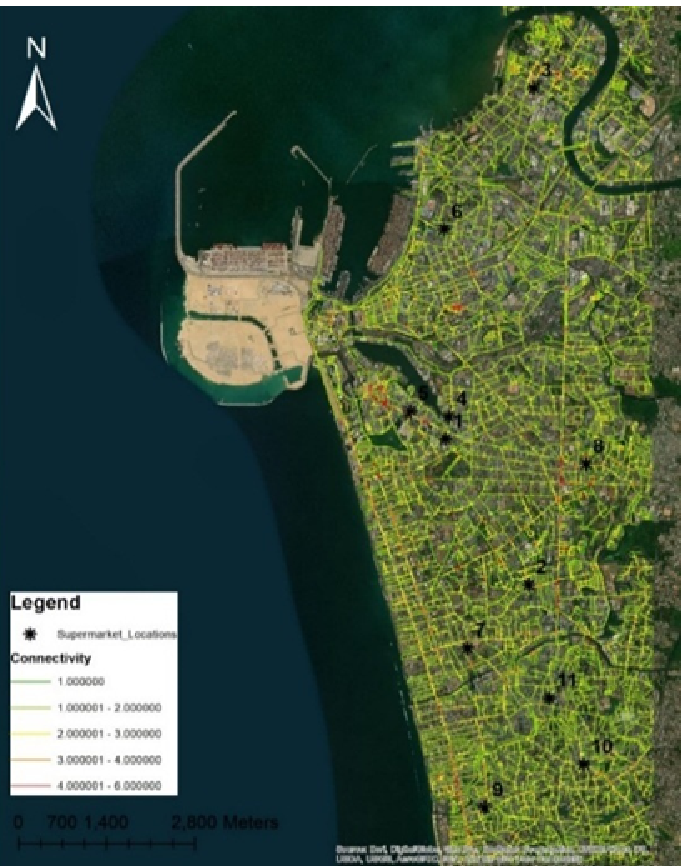

Figure 2: Connectivity

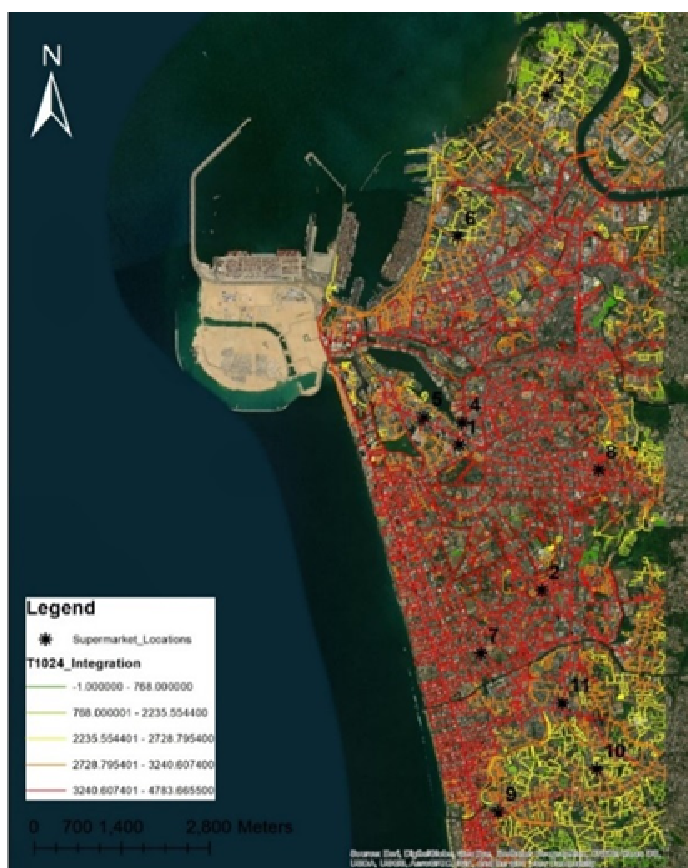

Figure 3: Angular Connectivity

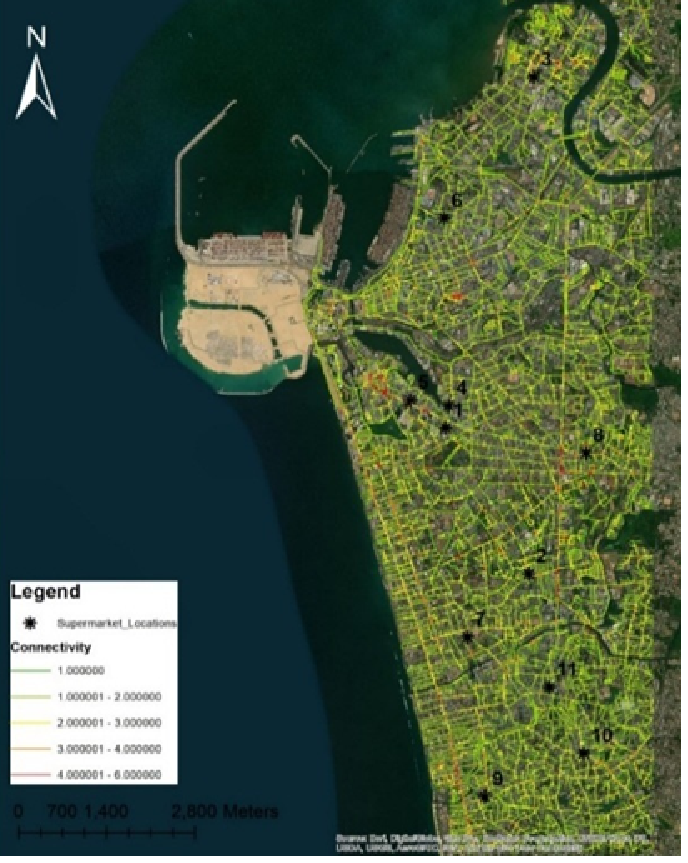

Figure 4: Choice 


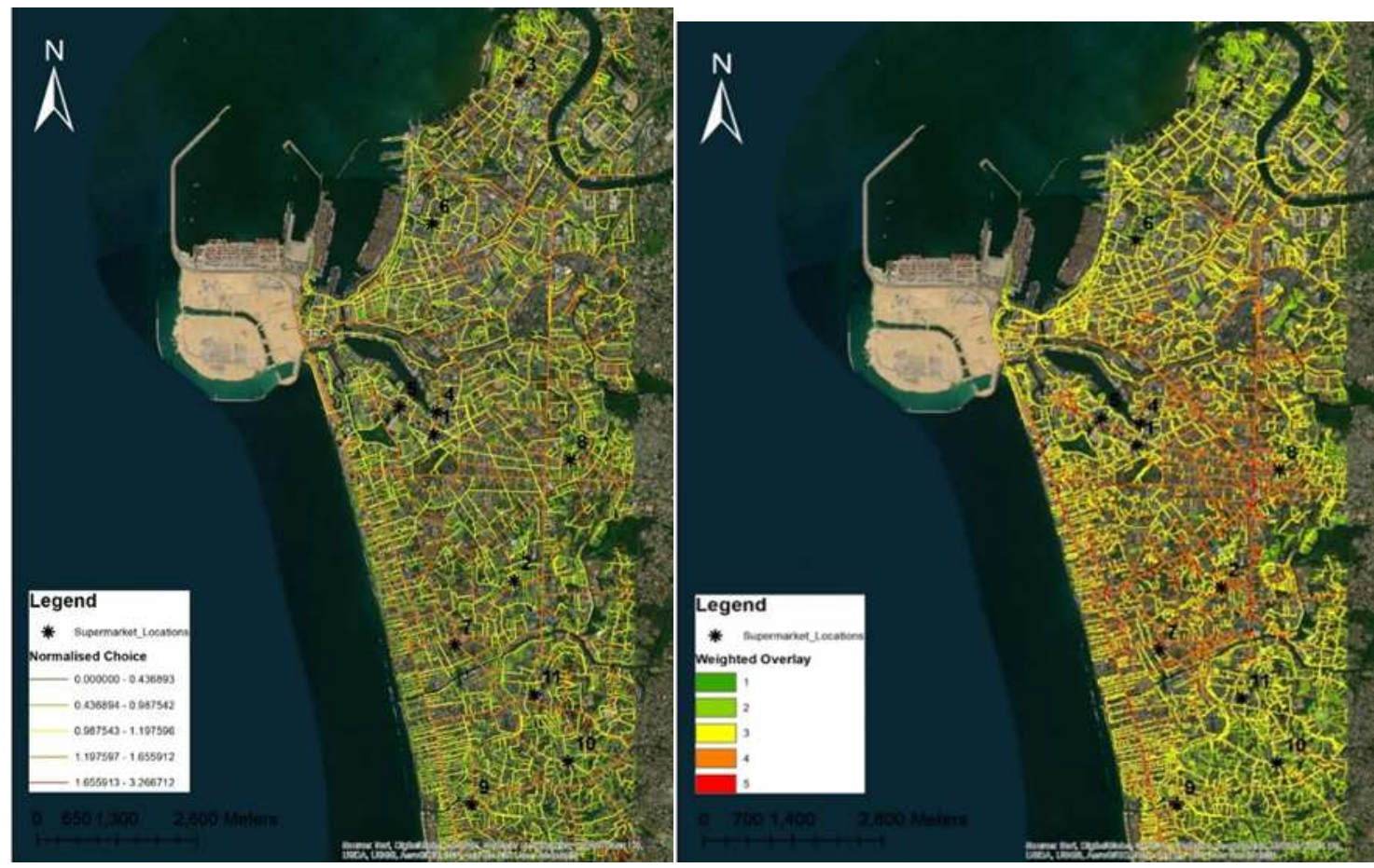

Figure 5: Normalized Choice

Figure 6: Weighted Overlay (Integration + Connectivity)

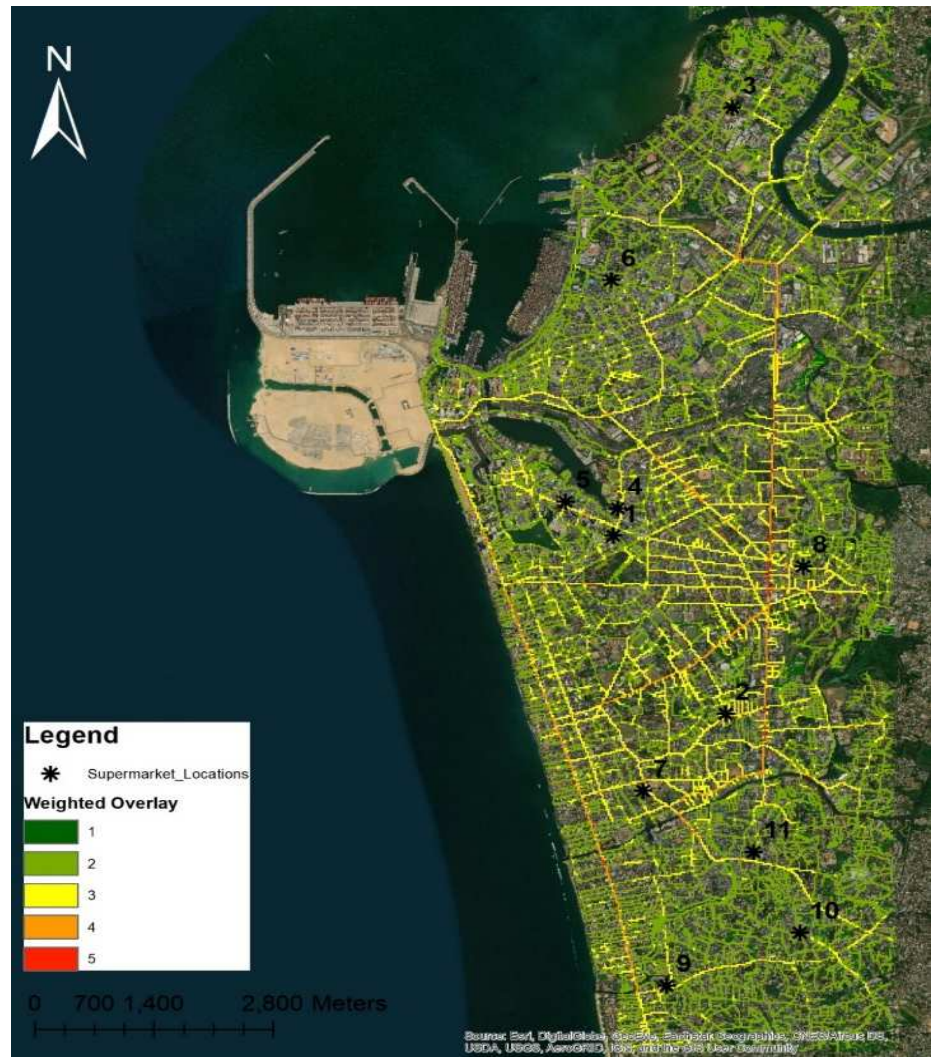

Figure 7: Weighted Overlay (Integration + Connectivity + Choice)

The overlay analysis is applied for integration and connectivity factors by using the GIS weighted overlay spatial analyst tool at equal influence to measure the overall integration and connectivity near the supermarket locations. 
According to the results, supermarket No: 3 and 10 have moderate value and other locations have high or very high connectivity and integration. As an average, very high integration and very high connectivity can be observed at supermarkets (Figure 6). Thus, the overlay analysis is applied for integration, choice and connectivity factors by using the GIS weighted overlay spatial analyst tool at equal influence to measure the overall spatial configuration near the supermarket locations. According to the results, supermarket No: 3 and 10 have low value, supermarket No: 1,4,5,6, 9, and 11 have moderate value and supermarket No: 2,7 and 8 have high overall value. As an average, a high integration, high choice and high connectivity can be observed at supermarkets (Figure 7).

The results show the where people are gathering, how people are moving, how they adapt to space and how they develop the space etc. All analyzed maps represent how people experience on the space around as below tables.

Table 3: Results from Spatial Analysis

\begin{tabular}{|c|c|c|c|c|c|c|c|}
\hline Ż & 氖 & 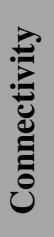 & 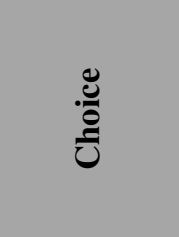 & 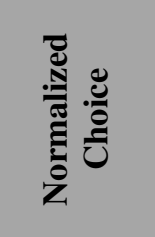 & 音泀 & 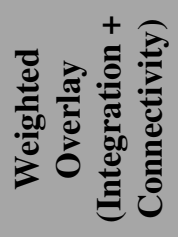 & 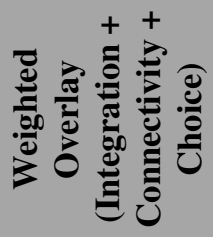 \\
\hline 1 & 3534.3047 & 4 & 33800816 & 1.323221 & 2.227553 & 4 & 3 \\
\hline 2 & 4258.0464 & 3 & 22027148 & 1.309113 & 1.952432 & 5 & 4 \\
\hline 3 & 2687.2329 & 4 & 47058280 & 1.320488 & 1.91481 & 3 & 2 \\
\hline 4 & 3687.0352 & 3 & 32536938 & 1.324464 & 2.015446 & 4 & 3 \\
\hline 5 & 3530.4666 & 4 & 25674772 & 1.302002 & 1.996631 & 4 & 3 \\
\hline 6 & 2838.7063 & 4 & 369410 & 1.164999 & 2.572939 & 4 & 3 \\
\hline 7 & 4158.4785 & 4 & 42561212 & 1.375324 & 2.101505 & 5 & 4 \\
\hline 8 & 4190.6514 & 4 & 60260872 & 1.385233 & 2.071321 & 5 & 4 \\
\hline 9 & 3562.925 & 3 & 170953330 & 1.447633 & 1.993693 & 4 & 3 \\
\hline 10 & 2792.0864 & 3 & 4418502 & 1.147169 & 1.990058 & 3 & 2 \\
\hline 11 & 3339.8567 & 4 & 124927420 & 1.424382 & 1.968135 & 4 & 3 \\
\hline
\end{tabular}

Table 4: Results from Spatial Analysis

\begin{tabular}{|c|c|c|c|c|c|c|c|}
\hline 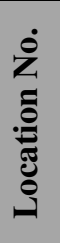 & 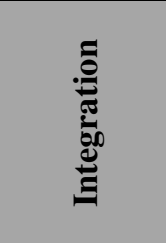 & ن & 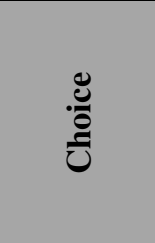 & 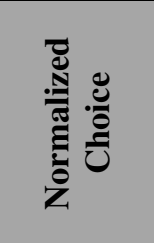 & 売 & 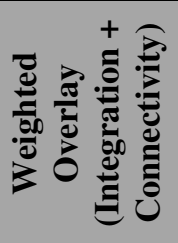 & 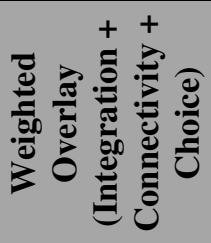 \\
\hline 1 & Very High & High & Low & High & $\begin{array}{l}\text { Very } \\
\text { High }\end{array}$ & High & Moderate \\
\hline 2 & Very High & Moderate & Low & High & $\begin{array}{l}\text { Very } \\
\text { High }\end{array}$ & Very High & High \\
\hline 3 & Moderate & High & Moderate & High & $\begin{array}{l}\text { Very } \\
\text { High }\end{array}$ & Moderate & Low \\
\hline 4 & Very High & Moderate & Low & High & $\begin{array}{l}\text { Very } \\
\text { High }\end{array}$ & High & Moderate \\
\hline 5 & Very High & High & Low & High & $\begin{array}{l}\text { Very } \\
\text { High }\end{array}$ & High & Moderate \\
\hline 6 & High & High & $\begin{array}{l}\text { Very } \\
\text { Low }\end{array}$ & Moderate & $\begin{array}{l}\text { Very } \\
\text { High }\end{array}$ & High & Moderate \\
\hline 7 & Very High & High & Moderate & High & $\begin{array}{l}\text { Very } \\
\text { High }\end{array}$ & Very High & High \\
\hline 8 & Very High & High & Moderate & High & $\begin{array}{l}\text { Very } \\
\text { High }\end{array}$ & Very High & High \\
\hline
\end{tabular}




\begin{tabular}{|c|c|c|c|c|c|c|c|}
\hline 9 & Very High & Moderate & High & High & $\begin{array}{c}\text { Very } \\
\text { High }\end{array}$ & High & Moderate \\
\hline 10 & High & Moderate & $\begin{array}{c}\text { Very } \\
\text { Low }\end{array}$ & Moderate & $\begin{array}{c}\text { Very } \\
\text { High }\end{array}$ & Moderate & Low \\
\hline 11 & Very High & High & High & High & $\begin{array}{c}\text { Very } \\
\text { High }\end{array}$ & High & Moderate \\
\hline
\end{tabular}

Table 5: Results of Descriptive Statistics

\begin{tabular}{|c|c|c|c|c|c|c|c|}
\hline \multicolumn{8}{|c|}{ Statistics } \\
\hline & $\begin{array}{c}\text { Integratio } \\
\mathbf{n}\end{array}$ & $\begin{array}{c}\text { Connectivit } \\
\mathbf{y}\end{array}$ & Choice & $\begin{array}{c}\text { Normalize } \\
\text { d Choice }\end{array}$ & $\mid \begin{array}{c}\text { Angular } \\
\text { Connectivi } \\
\text { ty }\end{array}$ & \begin{tabular}{|c} 
Weighted \\
Overlay \\
(Integration \\
+ \\
Connectivit \\
y) \\
\end{tabular} & $\begin{array}{c}\text { Weighted } \\
\text { Overlay } \\
\text { (Integration } \\
+ \\
\text { Connectivity } \\
+ \text { Choice) }\end{array}$ \\
\hline Valid & 11 & 11 & 11 & 11 & 11 & 11 & 11 \\
\hline Missing & 0 & 0 & 0 & 0 & 0 & 0 & 0 \\
\hline Mean & 3507.2536 & 3.6364 & 51326245.4545 & 1.3204 & 2.0731 & 4.0909 & 3.0909 \\
\hline Median & 3534.3047 & 4.0000 & 33800816.0000 & 1.3232 & 1.9966 & 4.0000 & 3.0000 \\
\hline Mode & $2687.23^{\mathrm{a}}$ & 4.00 & $369410.00^{\mathrm{a}}$ & $1.15^{\mathrm{a}}$ & $1.91^{\mathrm{a}}$ & 4.00 & 3.00 \\
\hline $\begin{array}{c}\text { Std. } \\
\text { Deviation }\end{array}$ & 561.28272 & .50452 & 51842251.66133 & .09427 & .18642 & .70065 & .70065 \\
\hline Variance & $\begin{array}{c}315038.28 \\
7\end{array}$ & .255 & $\begin{array}{c}26876190573169 \\
99.000\end{array}$ & .009 & .035 & .491 & .491 \\
\hline Range & 1570.81 & 1.00 & 170583920.00 & .30 & .66 & 2.00 & 2.00 \\
\hline Minimum & 2687.23 & 3.00 & 369410.00 & 1.15 & 1.91 & 3.00 & 2.00 \\
\hline Maximum & 4258.05 & 4.00 & 170953330.00 & 1.45 & 2.57 & 5.00 & 4.00 \\
\hline & & & & 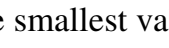 & is sn & & \\
\hline
\end{tabular}

According to the results of Descriptive Statistics from SPSS Statistics software, most supermarkets are demanded to locate at a very highly integrated and highly connected location with very high angular connectivity. Thus, they are attracted to locate highly easy locations to connect to the road network. According to the weighted overlay analysis, supermarkets are located at the very highly connected and very highly integrated location. Elsewise, they are located at high integrated, highly connected and highly closer to the street network.

\section{CONCLUSIONS}

This paper illustrates the spatial pattern based on space syntax and GIStechnique to identify the aggregate traffic flow distribution in an urban context. The results described the condition of urban transportation performance on road configuration. The preliminary findings of this paper explain that high vehicle attraction and high urban configuration happens at the topological locations which are more integrated and more compacted road arrangements. Thus, this paper finds that spatial activity patterns based on the spatial configuration in Colombo city tend to be concentrated along the major roads as a linear form. This is essential for planning interventions of new cities or else for erasing the prevailing issues in existing cities. On the other hand, retail activities can make decisions to develop based on the spatial characteristics of the current city.

\section{ACKNOWLEDGEMENTS}


Authors would like to offer respected thanks to Department of Town and Country Planning, the University of Moratuwa for the guidance to this research development.

\section{REFERENCES}

1. A. Alexander, D. Cryer and S. Wood, "Location planning in charity retailing," International Journal of Retail \& Distribution Management, vol. 36, 2008.

2. Z. Han, X. Cui, Z. Wang and G. Chen, "Identifying Spatial Patterns of Retail Stores in Road Network Structure," August 2019.

3. I. Omer and R. Goldblatt, "Spatial patterns of retail activity and street network structure in new and traditional Israeli cities," Urban Geography, 2015, 01 December 2015.

4. P. Mokhtarian and I. Salomon, "How Derived is the Demand for Travel? Some Conceptual and Measurement Considerations," pp. 695-719, 01 September 2001.

5. B. Prideaux, "The role of the transport system in destination development," vol. , no. , pp. 53-63, 2000.

6. J. Wang, Using network analysis to explore the effects of road network on traffic congestion and retail store sales, 2017.

7. R. H. M. Pereira, F. R. B. d. Holanda, V. A. S. d. Medeiros and A. P. B. G. Barros, "The Use of Space Syntax in Urban Transport Analysis: Limits and Potentials," Institute for Applied Economic Research, 2015.

8. G. Rybarczyk and $C$. Wu, "Examining the impact of urban morphology on bicycle mode choice," Environment and Planning B: Planning and Design 2013, vol. 40, January 2014.

9. L. Marcus, S. Alexander and M. Dahlhielm, "Architectural Knowledge and Complex Urban Space - Analysis of Five Proposals for Slussen in Stockholm," The Journal of Space SyntaxThe Journal of Space Syntax, vol. 1, no. 1, pp. 177-198, July 2010.

10. B. Hillier, Space is the machine -, 2007.

11. J. L. Patterson, "Traffic modelling in cities - validation of space syntax at an urban scale," July 2016.

12. J. Gil, E. Tobari, M. Lemlij, A. Rose and A. Penn, "The Differentiating Behaviour of Shoppers - Clustering of Individual Movement Traces in a Supermarket," Proceedings of the 7th International Space Syntax Symposium, pp. 23:1-36:13.

13. Y. Fang, J. Mao, Q. Liu and J. Huang, "Exploratory space data analysis of spatial patterns of large-scale retail commercial facilities: The case of Gulou District, Nanjing, China," ScienceDirect, 2020.

\section{AUTHORS}

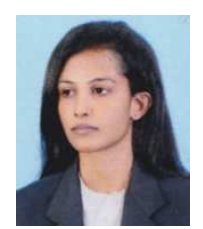

\section{A.L. AmaliChathurikaPathiraja}

B.Sc. (Hons) (Town \& Country Planning)

Ms. AmaliPathiraja is a Postgraduate Student of Department of Town \& Country Planning, University of Moratuwa, Sri Lanka. 


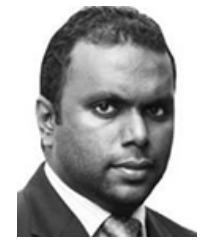

\section{P.C.P. De Silva}

B.Sc. (Hons) (Town \& Country Planning)

B.Sc. (Hons) in Computing (University of Greenwich, UK)

$\mathrm{PhD}$ (Civil Engineering, SL)

Dr. P.C.P. De Silva is working as a senior lecturer at the Department of Town \& Country Planning, University of Moratuwa, Sri Lanka.

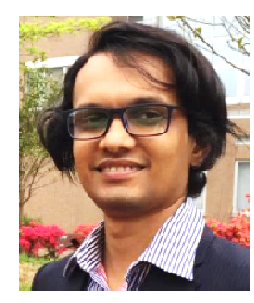

\section{AmilaJayasinghe}

B.Sc. (Hons) (Town \& Country Planning); M.Plan.(Infrastructure Planning) India, D.Eng.(NUT, Japan); MITP(Sri Lanka) Chartered Town Planner

Dr. Jayasinghe is working as a senior lecturer at the Department of Town \& Country Planning, University of Moratuwa, Sri Lanka. 

